\title{
Isolasi Bakteri Endofit Pelarut Fosfat Pada Tanaman Padi (Oryza sativa) var.situbagendit
}

\section{Isolation Phosphate Solvent Endophytic Bacteria From Roots Oryza sativa var.situbagendit}

\author{
Dyah Ayu Sri Hartanti ${ }^{1}$ \\ ${ }^{I}$ Fakultas Pertanian, Universitas KH. A. Wahab Hasbullah \\ Email:adyah674@yahoo.com ${ }^{1}$
}

\begin{abstract}
Abstrak
Bakteri endofit adalah bakteri yang menginvasi jaringan tanaman dan mempunyai peranan terhadap pertumbuhan tanaman salah satunya adalah kemampuannya dalam pelarutan fosfat. Ketersediaan unsur fosfat sangatlah penting untuk pertumbuhan tanaman. Pada penelitian ini isolasi dan identifikasi bakteri endofit diambil dari akar tanaman padi varietas situbagendit. Dari hasil isolasi bakteri endofit tersebut didapatkan 4 jenis isolat yaitu EPS1, EPS2, EPS3, dan EPS4. Masing-masing isolat tersebut adalah genus dari Pseudomonas, Bacillus, Enterobacter, dan Azotobacter. Dalam pengukuran indeks pelarutan fosfat, isolat EPS2 merupakan isolat yang paling tinggi dalam pelarutan fosfat yaitu memiliki nilai IP sebesar 2,07.
\end{abstract}

Kata Kunci: Bakteri endofit, padi varietas situbagendit, isolasi, identifikasi, fosfat.

\section{PENDAHULUAN}

Padi (Oryza sativa) adalah salah satu tanaman pertanian yang mempunyai peran penting bagi kehidupan di dunia yaitu sebagai sumber makanan pokok. Masyarakat di Desa Genreng, Kecamatan Tikung, Kabupaten Lamongan sebagian besar menggunakan bibit padi varietas situ bagendit yang mempunyai masa tanam antara 110 hingga 120 hari. Sebagian besar petani meningkatkan pertumbuhan tanaman padi dengan menggunakan pupuk sintetis. Aplikasi dan pemberian pupuk sintetis dalam jangka waktu panjang menyebabkan penurunan kesuburan tanah (Hartanti, 2020).

Bakteri di dalam tanah mempunyai peranan yang spesifik yang dapat mendukung pertumbuhan tanaman. Bakteri tersebut dikenal sebagai Plant Growth Promotion Bacteria (PGPB) (Tarabily et al., 2003). Bakteri mampu melakukan migrasi ke dalam tanaman dan menghasilkan senyawa tertentu yang sama dengan yang dihasilkan oleh tanaman inangnya (Tarabily et al., 2003). Bakteri yang terdapat pada jaringan tanaman disebut sebagai bakteri endofit. Jaringan tanaman yang dapat dilakukan isolasi bakteri endofit adalah biji, akar, batang, dan daun dalam keadaan yang steril. Peranan dari bakteri endofit sangat banyak, salah satunya yaitu mampu meningkatkan pertumbuhan tanaman dengan menghasilkan atau menyediakan unsur untuk memenuhi kebutuhan tanaman, salah satu unsur yang diperlukan oleh tanaman salah satunya yaitu fosfat (Khan $e t$ al., 2009).

Pada analisa suatu lahan pertanian diketahui unsur fosfat sangat tinggi, namun tidak dapat tersedia oleh tanaman, yang artinya tanaman tidak dapat menggunakan fosfat untuk kebutuhan metabolismenya, hal tersebut kemungkinan karena dipengaruhi oleh $\mathrm{pH}$ tanah dan juga adanya komponen berupa alumuniun, besi, dan kalsium pada tanah tersebut yang mampu melakukan pengikatan unsur fosfat, sehingga fosfat tidak dapat digunakan oleh tanaman (Lal, 2002). Agar unsur hara fosfat dapat tersedia oleh tanaman, maka memerlukan bantuan mikroorganisme yaitu bakteri pelarut fosfat, salah satunya yaitu kelompok Bacillus dan Pseudomonas, sehingga penyerapan fosfat oleh tanaman dapat meningkat (Khan et al., 2009). Melihat potensi bakteri endofit dalam menyediakan unsur hara fosfat untuk mendukung pertumbuhan tanaman dan pentingnya ketersedian padi sebagai bahan makanan utama bagi masyarakat Indonesia, maka tujuan dari penelitian ini adalah melakukan isolasi bakteri yang terdapat pada jaringan tanaman padi varietas situ bagendit yang mempunyai kemampuan dalam pelarutan fosfat. 


\section{METODE PENELITIAN}

\section{Alat dan Bahan}

Alat yang digunakan dalam penelitian ini yaitu autoklaf, timbangan analitik, pinset, jarum ose, mikroskop, mortar, alu, erlenmeyer glass, pipet volume, incubator, penggaris, jangka sorong, cawan petri, tabung reaksi.

Bahan yang digunakan adalah akar padi varietas situbagendit yang berumur 45 hari, akuades steril, bahan kimia yaitu etanol 75\%, sodium hipoklorit 5\%, Nutrient Agar (Oxoid), Nutrient Broth (Oxoid), Pikovkaya Agar (Oxoid), kristal violet, safranin, dan iodium.

\section{Rancangan Penelitian}

Penelitian ini adalah jenis penelitian ekploratif pada tahap isolasi bakteri endofit dan uji bakteri pelarut fosfat dengan memperhatikan terbentuknya zona halo di sekitar koloni yang diinokulasikan dan menghitung indeks kelarutan (Nautiyal, 1999).

\section{Metode Analisis}

Analisis hasil penelitian ini baik tahap isolasi dan identifikasi bakteri endofit, serta skrining bakteri yang mampu dalam pelarutan fosfat dianalisis secara deskriptif kualitatif (Nautiyal, 1999).

\section{Tahapan Penelitian}

\section{Sterilisasi permukaan akar}

Sterilisasi permukaan akar dilakukan dengan merendam akar sebanyak 10 gram yang sudah bersih dari kotoran ke dalam $75 \%$ etanol selama 3 menit, selanjutnya akar direndam dalam larutan sodium hipklorit $5 \%$ selama 5 menit dan dibilas dengan air steril sebanyak lima kali (Mbai et al., 2013). Cara untuk mengetahui sterilisasi akar berhasil, maka akar yang sudah disterilkan dioleskan pada media Nutrient Agar dan di inokulasikan pula hasil bilasan terakhir aquades pada media Nutrient Agar, kemudian dilakukan pengamatan hasil sterilisasi setelah 24 jam. Berhasilnya sterilisasi ditunjukkan dengan tidak adanya bakteri ataupun kapang yang tumbuh pada media Nutrient Agar dan juga pada akar yang telah disterilkan (Etesami $e t$ al., 2014).

\section{Isolasi dan identifikasi bakteri endofit}

Akar yang telah steril dihaluskan menggunakan mortar dan pestle, lalu akar yang telah halus dimasukkan kedalam botol Erlenmeyer yang berisi $90 \mathrm{ml}$ akuades steril. Proses pengenceran dilakukan dengan cara mengambil $1 \mathrm{ml}$ suspensi yang dimasukkan kedalam $9 \mathrm{ml}$ akuades steril, pengenceran dilakukan hingga $10^{-3}$, kemudian $1 \mathrm{ml}$ suspensi hasil pengenceran diinokulasikan dengan metode tuang pada Nutrient Agar. Inkubasi dilakukan selama 3-5 hari di incubator pada suhu $28^{\circ} \mathrm{C}$ dalam keadaan aerob. Jumlah koloni yang tumbuh pada media dihitung dan dinyatakan dalam CFU (Colony Forming Units). Populasi bakteri dihitung sesuai koloni yang tumbuh pada media, penentuan jenis bakteri berdasarkan morfologi koloni bakteri. Masing-masing koloni bakteri yang terpilih di identifikasi secara makroskopis, mikroskopis dan uji fisiologis. Dari beberapa karakteristik tersebut selanjutnya di cocokkan dengan buku panduan Bergey's manual determination. Bakteri yang didapatkan dimurnikan pada media NA dan disimpan untuk digunakan pada tahap selanjutnya (Etesami et al., 2014).

\section{Uji bakteri yang berpotensi dalam pelarutan fosfat}

Kemampuan bakteri dalam pelarutan fosfat diuji pada media pikovskaya agar dengan metode inoculation spot dan di inkubasi selama tiga hari. Adanya zona bening disekitar koloni menunjukkan adanya pelarutan fosfat (Etesami et al., 2014). Terbentuknya zona halo diamati dan dihitung indeks pelarutan fosfat (Nautiyal, 1999).

\section{HASIL DAN PEMBAHASAN}

Hasil pengamatan secara makroskopis dan mikroskopis bakteri endofit yang ditemukan dari sampel akar tanaman padi 
varietas situbagendit yaitu diperoleh 4 jenis bakteri endofit yang diperlihatkan pada Tabel 1.1. Hasil pengamatan secara makroskopis maupun mikroskopis, keempat isolat bakteri ini mempunyai karakteristik yang beragam secara morfologi dan pengamatan pewarnaan Gram bakteri. Koloni beberapa isolat tersebut mempunyai bentuk round dan mempunyai warna krem. Tepi koloni sangat bervariasi dengan tipe undulate (rata), lobbate, serrat, dan round. Tipe elevasi koloni bakteri pada media juga beragam dengan tipe elevasi raised dan conveks (cembung), sedangkan hasil pengamatan secara mikroskopis dengan pewarnaan gram diperoleh tiga isolat bakteri Gram negatif dan satu isolat bakteri Gram positif yang didominasi bentuk batang yang ditunjukkan pada Gambar 1.

Tabel 1.1 Karakteristik makroskopis dan mikroskopis isolat bakteri endofit dari akar tanaman padi varietas situ bagendit

\begin{tabular}{|c|c|c|c|c|}
\hline \multirow{2}{*}{ Morfoligi isolat } & \multicolumn{4}{|c|}{ Jenis isolat } \\
\cline { 2 - 5 } & EPS1 & EPS2 & EPS3 & EPS4 \\
\hline \multicolumn{5}{|c|}{ Makroskopis koloni } \\
\hline Warna & Krem & Krem & Bening & Kuning \\
\hline Ukuran & Kecil & Kecil & Kecil & Kecil \\
\hline Bentuk koloni & Bulat & Irregular & Bulat & Bulat \\
\hline Elevasi & Conveks & Conveks & Conveks & Raised \\
\hline Margin & Round & Serrate & Lobate & Undulate \\
\hline Permukaan & Halus & Halus & Halus & Halus \\
\hline \multicolumn{5}{|c|}{} \\
\hline Mikroskopis koloni \\
\hline Bentuk sel & Batang & Batang & Batang & Cocoid \\
\hline Gram sel & Negatif & Positif & Negatif & Negatif \\
\hline Motilitas & Positif & Positif & Positif & Positif \\
\hline Endospora & Negatif & Positif & Negatif & Negatif \\
\hline
\end{tabular}

Adanya keragaman bentuk sel bakteri salah satunya karena adanya pengaruh lingkungan atau habitat dari bakteri tersebut

keragaman bentuk bakteri dipengaruhi oleh Selain karena faktor lingkungan, adanya usia bakteri dan faktor nutrisi yang diperlukan untuk regenerasi bakteri (Ilyas, 2001).

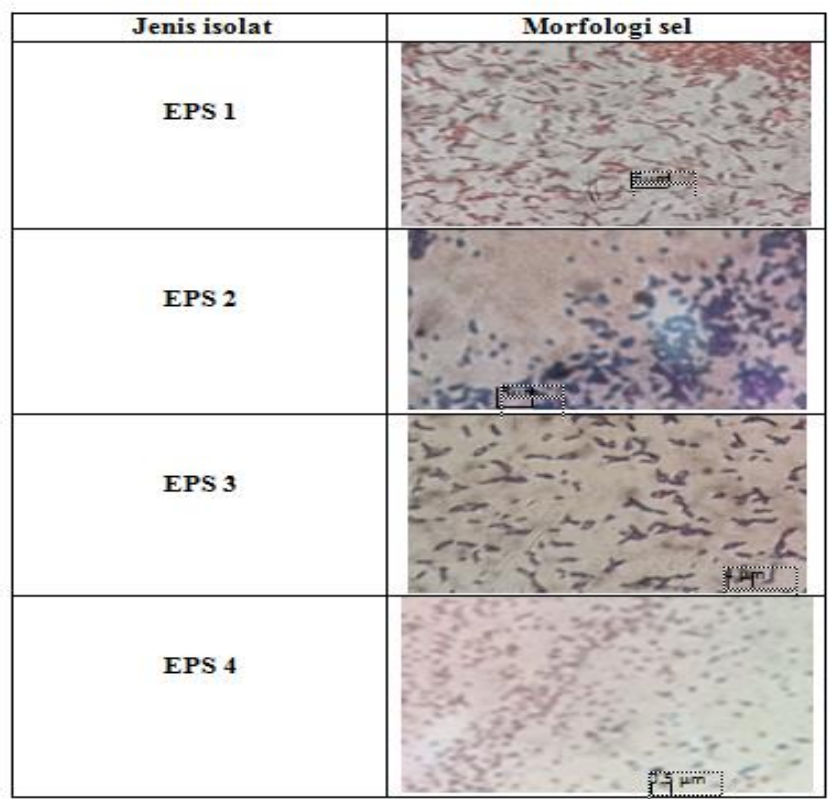

Gambar 1. Hasil pewarnaan Gram isolat bakteri endofit dari akar tanaman padi varietas situ bagendit 
Berdasarkan perbedaan karakteristik makroskopis dan mikroskopis masingmasing isolat diatas, selanjutnya dilakukan uji fisiologis dan kemudian dilakukan proses identifikasi. Bakteri yang tumbuh pada suatu media, dapat ditentukan jenisnya dengan cara mengamati perubahan warna media tumbuhnya, hal tersebut dikarenakan setiap jenis bakteri mampu menghasilkan hasil metabolitnya atau menggunakan media untuk kepentingan metabolismenya sehingga dapat mempengaruhi warna pada medianya (Ilyas, 2001). Metode identifikasi isolat bakteri pada penelitian ini menggunakan teknik konvensional. Metode tersebut dilakukan dengan cara melakukan perbandingan bakteri yang berhasil ditemukan dengan bakteri yang sudah ditemukan sebelumnya dan berhasil teridentifikasi. Apabila proses identifikasi tidak ada kesamaan 100\% dengan bakteri yang telah ada sebelumnya, maka dapat dilakukan pendekatan yang paling sesuai kesamaannya. Pengamatan secara fisiologis masing-masing isolat yang diperoleh dari akar padi varietas situbagendit disajikan pada Tabel 1.

Tabel 1.2. Karakteristik fisiologis hasil uji TSIA (Triple Sugar Iron Agar), MR-VP (Methyl Red-Voges Proskauer), SCA (Simmon Citrate Agar), motilitas, katalase

\begin{tabular}{|c|c|c|c|c|c|c|c|c|c|c|}
\hline \multirow{2}{*}{$\begin{array}{l}\text { Nama } \\
\text { Isolat }\end{array}$} & \multicolumn{4}{|c|}{ Uji } & \multirow[b]{2}{*}{ MR } & \multirow[b]{2}{*}{ VP } & \multirow{2}{*}{$\frac{\text { Uji }}{\text { Motil }}$} & \multirow{2}{*}{$\begin{array}{c}\text { Motilitas } \\
\text { Indol }\end{array}$} & \multirow{2}{*}{$\begin{array}{l}\text { Uji } \\
\text { Ktls }\end{array}$} & \multirow{2}{*}{$\begin{array}{l}\text { Uji } \\
\text { St }\end{array}$} \\
\hline & Slant & Butt & Gas & H2S & & & & & & \\
\hline EPS 1 & Merah & Kuning & - & - & - & + & + & + & + & + \\
\hline EPS 2 & Merah & Kuning & - & - & + & - & + & + & + & + \\
\hline EPS 3 & Merah & Kuning & - & - & $=$ & + & + & + & + & + \\
\hline EPS 4 & Merah & Kuning & + & $=$ & + & + & + & + & + & + \\
\hline
\end{tabular}

Berdasarkan karakteristik yag didapatkan secara mikroskopis, makroskopis, dan fisiologis, maka dapat dilakukan proses identifikasi dengan menggunakan buku panduan Bergey's manual determination untuk mengetahui jenis genus dari keempat isolat yang berhasil diisolasi. Dari keempat isolat tersebut masing-masing yaitu EPS1 adalah genus dari Pseudomonas, isolat EPS2 adalah genus dari Bacillus, isolat EPS3 adalah genus Enterobacter, isolat EPS4 adalah salah satu spesies dari genus Azotobacter.

Kelimpahan populasi bakteri rhizosfer lebih banyak jika dibandingkan dengan bakteri yang masuk ke dalam jaringan tanaman, hal ini dipengaruhi oleh faktor internal atau dari bakteri itu sendiri maupun faktor eksternal atau faktor lingkungan yang dapat berupa faktor abiotik (Roesc et al., 2006). Faktor yang berasal dari bakteri itu sendiri maupun dari tanaman yang menjadi kolonisasi bakteri yaitu struktur morfologi dan anatomi tanaman, jenis bakteri, umur tanaman, dan enzim yang mampu dikeluarkan oleh bakteri tersebut (Altalhi, 2009). Faktor abiotik yang berperan yaitu salah satunya penggunaan pupuk sintetis yang sangat tinggi yang dapat mempengaruhi keberadaan bakteri tanah dan mengganggu kemampuan bakteri endofit dalam melakukan migrasi kedalam jaringan tanaman.

Jaringan tanaman yang berhasil di invasi oleh bakteri menunjukkan kecocokkan satu sama lain atau bersifat sinergis, demikian pula dengan bakteri endofit yang berhasil ditemukan pada akar tanaman padi varietas situbagendit yang terdiri spesies Pseudomonas, Bacillus, Enterobacter, dan Azotobacter. Bakteri yang berhasil diisolasi merupakan bakteri yang secara umum berada pada daerah rhizosfer yang diketahui mampu melakukan peningkatan pada proses pertumbuhan dan perkembangan tanaman. Proses terjadinya 
kolonisasi karena adanya komunikasi yang dilakukan oleh bakteri dengan tanaman melalui sinyal molekul yang ada (Long et al., 2008, Rosenblueth dan Romero, 2006). Melalui mekanisme sinyal yang ada memungkinkan bakteri memberikan respon penyesuaian diri populasi terhadap tanaman inang, seperti peningkatan kepadatan populasi sel bakteri, sehingga quorum sensing adalah pemicu respon fisiologi yang membantu untuk konservasi energi, produksi antibiotik, maupun exoenzym oleh bakteri bagi tanaman inang (Hudson et al., 2010).

Hasil pengukuran indeks pelarutan fosfat yang ditunjukkan pada tabel 1.3 diperoleh isolat EPS2 tertinggi dalam kemampuan pelarutan fosfat dengan nilai IP (solubilization index) sebesar 2,07.

Tabel 1.3 Nilai kemampuan pelarutan fosfat oleh bakteri endofit varietas situ bagendit

\begin{tabular}{|c|c|c|c|}
\hline Jenis isolat & $\begin{array}{c}\text { Diameter koloni } \\
(\mathbf{c m})\end{array}$ & $\begin{array}{c}\text { Diameter zona } \\
\text { halo }(\mathbf{c m})\end{array}$ & Solubilization index \\
\hline EPS1 & 1.2 & 3.5 & 1.91 \\
\hline EPS2 & 1.3 & 4.0 & 2.07 \\
\hline EPS3 & 1.3 & 1.6 & 0.23 \\
\hline EPS4 & 1.2 & 3.4 & 1.83 \\
\hline
\end{tabular}

Fosfat yang tersedia di alam dapat berupa fosfat organik dan fosfat anorganik. Tersedianya fosfat organik berasal dari komponen makhluk hidup yaitu misalnya tumbuhan, hewan, dan mikroorganisme yang berupa fosfolipid daan fitin (Rao, 1994). Pelarutan fosfat secara biologis terjadi ketika mikroba menghasilkan enzim fosfatase dan enzim fitase (Alexander, 1977). Fosfatase merupakan enzim yang akan dihasilkan apabila ketersediaan fosfat rendah. Fosfatase dieksresikan oleh akar tanaman dan mikroba sehingga mampu membebaskan ion fosfat terikat dan oleh karena itu dapat fosfat dapat diserap oleh tanaman (Alexander, 1977). Kemampuan genus Bacillus dan Pseudomonas dalam melakukan pelarutan fosfat karena mampu menghasilkan asam organik yaitu sebagai contoh asam formiat, asetat dan lasam aktat. Asam organik tersebut mampu melarutkan fosfat, sehingga membuat fosfat yang tidak tersedia menjadi fosfat yang tersedia bagi tanaman, sehingga mikrooragnisme tanah yang berperan dalam pelarutan fosfat mempunyai peran penting untuk menanggulangi defisiensi fosfat pada tanaman (Kang et al., 2007; Chaiharn et al., 2008; Park et al., 2009; Mehrab et al., 2010).

Terbentuknya zona halo pada media pikovkaya agar karena adanya pelarutan suspensi trikalsium fosfat oleh bakteri yang mampu melarutkan trikalsium fosfat tersebut (Alam et al, 2002) (Gambar 2).
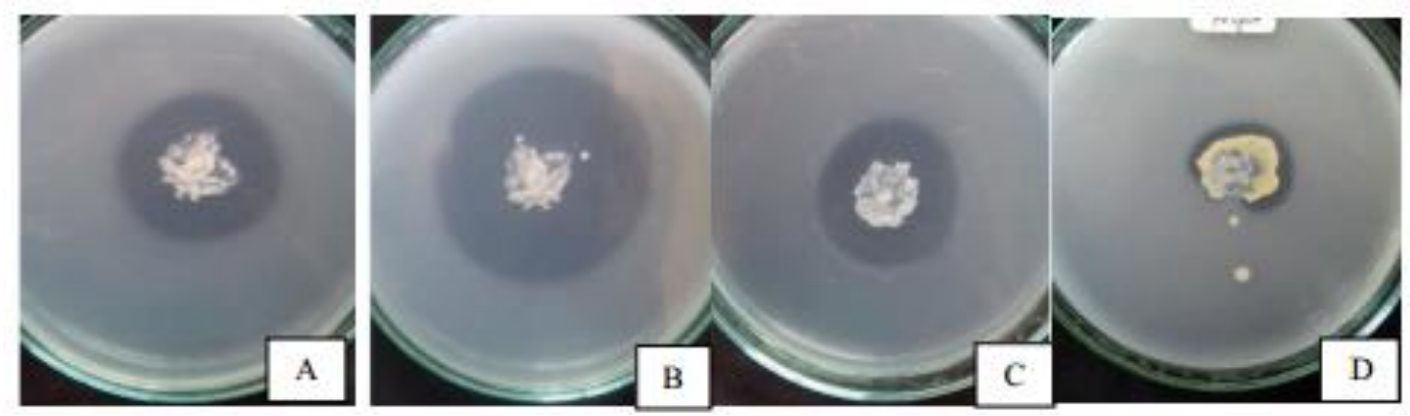

Gambar 2. Hasil positif bakteri mampu melakukan pelarutan fosfat dengan adanya zona halo yang terbentuk. Ket. $\mathrm{A}=$ isolat $\mathrm{EPS} 1 ; \mathrm{B}=$ isolat EPS2 ; $\mathrm{C}=$ isolat $\mathrm{EPS} 3$; $\mathrm{D}=$ isolat EPS4 


\section{KESIMPULAN}

Terdapat 4 jenis bakteri endofit pada tanaman padi (Oryza sativa) varietas situbagendit yaitu isolat EPS1 adalah genus Pseudomonas, isolat EPS2 adalah genus Bacillus, isolat EPS3 adalah genus Enterobacter, dan isolat EPS4 adalah genus Azotobacter. Keempat isolat bakteri endofit yang ditemukan mampu dalam pelarutan fosfat dan isolat EPS2 dari genus Bacillus mempunyai pelarutan fosfat tertinggi yaitu memiliki nilai IP sebesar 2,07.

\section{DAFTAR PUSTAKA}

Alam, S., Khalil, S., Ayub, N., dan Rashid, M. 2002. In vitro Solubilization of Inorganic Phosphate by Phosphate Solubilizing Microorganisms (PSM) from Maize Rhizosphere. International Journal of Agriculture \& Biology, Vol. 4, No. 4, h. 454-458.

Alexander, M. 1977. Introduction to Soil Mycrobiology. 2nd Edition. New York: John Wiley and Sons.

Altalhi, A.D. 2009. Plasmid Profiler, Antibiotic and Heavy Metal Resistance Incidence of endophytic bacteria isolated from Grampevine (Vitis vinifera L.). African Journal of Biotechnology. Vol. 8, No. 21, h. 5873-5882.

Chaiharn, M., Chunhaleuchan, S., Kozo, A., Lumyong, S. 2008. Screening of rhizobacteria for their plant growth promoting activities. KMITL Sci. Tech. J, Vol. 8, No. 1, h. 18-23.

Hartanti, Dyah. A. 2020. Biofertilizer Terhadap Kesuburan Tanah dan Pertumbuhan Tanaman. UNWAHA press.

Etesami, H., Mirsyed, Hosseini, H., Alikhani, H.A., Mohammadi, L. 2014. Bacterial biosynthesis of 1Aminocyclopropane-1Carboxylate (ACC) deaminase and Indole-3-Acetic Acid (IAA) as endophytic preferential selection traits by rice plant seedlings. J. Plant. Growth. Regul, h. 1-17.

Hudson, A.O., Ahmad, N.H., Buren, R. Van, dan Savka, M.A. 2010. Sugarcane and
Grapevine Endophytic Bacteria: Isolation, Detection of Quorum Sensing Signals and Identification by I6S v3 rDNA Sequence Analysist. Technology and Education Topics. Applies Microbiology and Microbial Biotechnology, h. 801-806.

Ilyas, S. 2001. Mikrobiologi Dasar. Medan: Universitas Sumatera Utara press.

Kang, S.H., Cho, H.S., Cheong, H., Ryu, C.M., Kim, J.F., Park, S.H. 2007. Two bacterial entophytes eliciting plant growth promotion and plant defense on pepper (Capsicum annuum L.), J. Microbiol. Biotechnol. Vol. 27, h. 96103.

Khan, A. Jilani A., Jilani, G., Akhtar, M. S., Naqvi, S. M. S., dan Rasheed, M. 2009. Phosphorus Solubilizing Bacteria:Occurrence,Mechanisms and their Role in Crop Production. Journal Agriculture Biol. Sci., Vol. 1, h. 48-58.

Lal, L. 2002. Phosphate Biofertilizer. India: Agrotech. Publ. Academy.

Long, H. H., Schmidt, D. D., dan Baldwin, I. T. 2008. Native Bacterial Endophytes Promote Host Growth in a SpeciesSpecific Manner; Phytohormone Manipulations Do Not Result in Common Growth Responses.

Mbai, F.N., Magiri, E.N., Matiru, V.N., Ng'ang'a, J., Nyambati, V.C.S. 2013. Isolation and Characterisation of Bacterial Root Endophytes with Potential to Enhance Plant Growth from Kenyan Basmati Rice, American International Journal of Contemporary Research, Vol. 3, No.4.

Nautiyal, C.S., 1999. An efficient microbiological growth medium for screening phosphate solubilizing microorganisms. FEMS Microbiol. Lett., Vol. 170, h. 265-270.

Rao, N.S. 1994. Mikroorganisme Tanah dan Pertumbuhan Tanaman Edisi Kedua. Jakarta: UI-Press.

Roesch, L.F.W., Olivares, F.L., Passaglia, L.M.P., Selbach, P.A., de Sá, E.L.S., de Camargo, F.A.O. 2006. 
Characterization of diazotrophic bacteria associated with maize: effect of plant genotype, ontogeny and nitrogen-supply. World J. Microbiol. Biotechnol. Vol. 22, h. 967-974.

Rosenblueth, M dan Martínez-Romero, E. 2006. The American Phytopathological Society. MPMI, Vol. 19, No. 8, h. 827-837.
Tarabily, K., Nassar, A. H., dan Sivasithamparam, 2003. Promotion Of Plant Growth By An Auxin-Producing Isolate Of The Yeast Williopsis Saturnus Endophytic In Maize Roots. The Sixth U. A. E University Research Conference. $h$. 60- 69. 